\title{
Molecular dissection of germline chromothripsis in a developmental context using patient-derived iPS cells
}

Sjors Middelkamp ${ }^{1}$, Sebastiaan van Heesch ${ }^{1,2}$, A. Koen Braat ${ }^{3}$, Joep de Ligt ${ }^{1}$, Maarten van Iterson ${ }^{4}$, Marieke Simonis ${ }^{5}$, Markus J. van Roosmalen ${ }^{1}$, Martijn J. E. Kelder ${ }^{6}$, Evelien Kruisselbrink, Ron Hochstenbach', Nienke E. Verbeek ${ }^{8}$, Elly F. Ippel ${ }^{8}$, Youri Adolfs ${ }^{9}$, R. Jeroen Pasterkamp ${ }^{9}$, Wigard P. Kloosterman ${ }^{1}$,

Ewart W. Kuijk ${ }^{1 *}$ and Edwin Cuppen ${ }^{1 *}$

\begin{abstract}
Background: Germline chromothripsis causes complex genomic rearrangements that are likely to affect multiple genes and their regulatory contexts. The contribution of individual rearrangements and affected genes to the phenotypes of patients with complex germline genomic rearrangements is generally unknown.

Methods: To dissect the impact of germline chromothripsis in a relevant developmental context, we performed trio-based RNA expression analysis on blood cells, induced pluripotent stem cells (iPSCs), and iPSC-derived neuronal cells from a patient with de novo germline chromothripsis and both healthy parents. In addition, $\mathrm{Hi}-\mathrm{C}$ and 4C-seq experiments were performed to determine the effects of the genomic rearrangements on transcription regulation of genes in the proximity of the breakpoint junctions.
\end{abstract}

Results: Sixty-seven genes are located within $1 \mathrm{Mb}$ of the complex chromothripsis rearrangements involving 17 breakpoints on four chromosomes. We find that three of these genes (FOXP1, DPYD, and TWIST1) are both associated with developmental disorders and differentially expressed in the patient. Interestingly, the effect on TWIST1 expression was exclusively detectable in the patient's iPSC-derived neuronal cells, stressing the need for studying developmental disorders in the biologically relevant context. Chromosome conformation capture analyses show that TWIST1 lost genomic interactions with several enhancers due to the chromothripsis event, which likely led to deregulation of TWIST1 expression and contributed to the patient's craniosynostosis phenotype.

Conclusions: We demonstrate that a combination of patient-derived iPSC differentiation and trio-based molecular profiling is a powerful approach to improve the interpretation of pathogenic complex genomic rearrangements. Here we have applied this approach to identify misexpression of TWIST1, FOXP1, and DPYD as key contributors to the complex congenital phenotype resulting from germline chromothripsis rearrangements.

Keywords: Chromothripsis, Complex genomic rearrangements, Congenital disorders, Induced pluripotent stem cells, Neuronal differentiation, RNA-sequencing, Chromosome conformation capture, TWIST1, Craniosynostosis, Personal genomics

\footnotetext{
* Correspondence: E.W.Kuijk-3@umcutrecht.nl; ecuppen@umcutrecht.nl

${ }^{1}$ Center for Molecular Medicine and Cancer Genomics Netherlands, Division Biomedical Genetics, University Medical Center Utrecht, Universiteitsweg 100, Utrecht 3584CG, The Netherlands

Full list of author information is available at the end of the article
} 


\section{Background}

Disruption of the genomic architecture by structural rearrangements such as translocations, deletions, duplications, and inversions is an important cause of congenital disease [1]. It has been estimated that approximately $15 \%$ of patients with multiple congenital abnormalities and/or mental retardation (MCA/MR) have a clinically relevant structural genomic rearrangement [2-5]. Some of these patients have very complex combinations of structural variants resulting from chromothripsis, the local shattering and reassembly of one or a few chromosomes in a single event [6-8]. Chromothripsis can occur in both somatic cells, where it can contribute to cancer, and germline cells, where it can lead to congenital disorders $[6,9,10]$. Congenital chromothripsis cases with up to 57 breakpoints involving one to five chromosomes have been described $[7,11]$. Determining the molecular and phenotypic consequences of genomic rearrangements is a major challenge, especially for patients with complex rearrangements that involve large genomic regions of several megabases on multiple chromosomes containing many genes and regulatory elements [12, 13]. Structural rearrangements may lead to altered gene expression, gene fusions, disruption of regulatory elements such as enhancers and boundaries of topologically associated domains (TADs), and/or unmasking of recessive mutations in the unaffected allele [12-16]. Due to the large number of potentially affected genes in patients with complex rearrangements, the molecular mechanisms that have contributed to their congenital phenotypes are often unknown. Transcriptome analysis is a powerful method to determine the functional molecular consequences of structural rearrangements [17-20]. Patients' blood cells are commonly used as the source for RNA-seq analysis because of the relatively easy accessibility of this material. However, genes potentially involved in the disease of a patient may be expressed differently or not at all in blood compared to the disease-relevant tissue [21, 22]. In addition, congenital disorders are typically the result of defects in developmental programs and it is questionable whether deregulation of developmental gene expression patterns persists in adult tissues. One approach that circumvents these concerns is to recapitulate certain developmental processes by generating induced pluripotent stem cells (iPSCs) from patients and differentiate these towards disease-relevant cell types [23-25]. This strategy has been applied successfully to improve our understanding of the molecular mechanisms underlying several (neuro-)developmental diseases such as schizophrenia and Rett syndrome [26, 27].

We previously performed RNA-seq on blood samples of patients with germline chromothripsis and identified several molecular phenotypes caused by the genomic rearrangements [19]. These included a hyper-activated trophoblast-specific miRNA cluster that interferes with embryonic brain development when ectopically expressed [19]. However, in a second patient with MCA/MR the relevance of the identified molecular effects to the phenotype could not be entirely resolved due to the complexity of the rearrangements [19]. In this study we further dissected the molecular consequences of chromothripsis by analyzing RNA expression and genome architecture in disease-relevant cell types derived from iPSCs from this patient and both parents.

\section{Methods}

\section{Derivation and cultivation of iPSCs}

Peripheral blood samples were obtained from a family trio consisting of the patient (child) with germline chromothripsis and both parents who served as controls. Peripheral blood mononuclear cells (PBMCs) were isolated by separation on a Ficoll-Paque TM PLUS gradient (GE Healthcare) with a density of $1.077 \mathrm{~g} / \mathrm{ml}$. Subsequently, CD34-positive cells were magnetically labeled with CD34-microbeads and purified with a CD34 Microbead kit (Miltenyi). The purified CD34-positive cells were resuspended in PBMC medium consisting of Iscove's modified Dulbecco's medium (ThermoFisher Scientific) with $5 \%$ fetal calf serum, $50 \mathrm{ng} / \mathrm{ml}$ stem cell factor, $50 \mathrm{ng} / \mathrm{ml}$ FLT3-ligand, $50 \mu \mathrm{M} \beta$-mercaptoethanol, $10 \mu \mathrm{g} / \mathrm{ml}$ penicillin, $10 \mu \mathrm{g} / \mathrm{ml}$ streptomycin, and $2 \mathrm{mM} \mathrm{L}$ glutamine, and plated in flat bottom 96-well ultra-low attachment plates. After 5 days, cells were passaged and the PBMC medium was further supplemented with $20 \mathrm{ng} / \mathrm{ml}$ interleukin (IL)-6 and $20 \mathrm{ng} / \mathrm{ml}$ thrombopoietin (TPO). After 7 days, cells were spin-transduced with $1 \mathrm{ml}$ OSKMdTOMATO lentivirus [28] supplemented with $8 \mu \mathrm{g} / \mathrm{ml}$ polybrene, $50 \mathrm{ng} / \mathrm{ml}$ stem cell factor, $50 \mathrm{ng} / \mathrm{ml}$ FLT3ligand, $20 \mathrm{ng} / \mathrm{ml} \mathrm{IL-6}$, and $20 \mathrm{ng} / \mathrm{ml} \mathrm{TPO}$ at $1800 \mathrm{rpm}$ at $32{ }^{\circ} \mathrm{C}$ for 100 minutes. Cells were subsequently incubated for $3 \mathrm{~h}$, after which medium was changed to PBMC medium supplemented with IL-6 and TPO. The spintransductions were repeated at day 9 and day 10 and cultures continued in PBMC medium supplemented with IL-6 and TPO. Subsequently all cells were seeded on irradiated mouse embryonic fibroblasts (Amsbio) and cultured in human embryonic stem cell (hESC) medium consisting of DMEM-F12 supplemented with $20 \%$ knock-out serum replacement, $10 \mu \mathrm{g} / \mathrm{ml}$ penicillin, $10 \mu \mathrm{g} / \mathrm{ml}$ streptomycin, $2 \mathrm{mM}$ L-glutamine, $0.1 \mathrm{mM}$ MEM-NEAA, $0.1 \mathrm{mM} \beta$-mercapthoethanol, and $10 \mathrm{ng} /$ $\mathrm{ml}$ basic fibroblast growth factor. The hESC medium was refreshed daily. Three clonal iPSC lines were derived from the patient, two lines from the father and one from the mother. The iPSCs were subsequently adapted to and cultured on Geltrex-coated plastic 
(ThermoFisher Scientific) in serum- and feeder-free Essential-8 medium (ThermoFisher Scientific) with $1 \times$ penicillin-streptomycin (ThermoFisher Scientific). All cell lines were free of mycoplasm contamination.

\section{Differentiation of iPSCs towards the neural lineage}

Differentiation of the iPSCs to neural progenitors was performed according to the protocol by Shi et al. [29] with several modifications. iPSCs were prepared for neural induction by culturing cells in three wells of a six-well plate to $90 \%$ confluency on Vitronectin-coated plates using the Essential-8 medium, after which cells were passaged in a 1:2 ratio to Geltrex-coated six-well plates. Cells were then cultured until 95-100\% confluency, upon which the medium was switched to neural induction medium. Neural induction medium was prepared with a 1:1 mixture of DMEM/F-12-Glutamax (Life Technologies) and Neurobasal medium (Life Technologies) with added $1 \times \mathrm{N}-2$ supplement (Life Technologies), $1 \times$ B-27 supplement (Life Technologies), $5 \mu \mathrm{g} / \mathrm{ml}$ insulin (Sigma), 2 mM L-glutamine (Life Technologies), 1× non-essential amino acids (Life Technologies), $100 \mu \mathrm{M}$ $\beta$-mercaptoethanol (Life Technologies), $1 \mu \mathrm{M}$ dorsomorphin (Sigma), and $10 \mu \mathrm{M}$ SB431242 (Tocris Bioscience). Medium was replaced daily. RNA was collected at days 0,7 , and 10 of differentiation. At day 10 , cells were passaged to laminin-coated coverslips for later immunofluorescent staining. Medium was then switched to neural maintenance medium (neural induction medium without dorsomorphin and SB431242), in which cells were cultured until formation of neural rosettes on day 15 after neural induction.

\section{Immunofluorescent labeling of cultured cells}

For immunofluorescent staining, cells were grown on coverslips, after which they were fixed in $4 \%$ paraformaldehyde for 15 minutes at room temperature (RT). Coverslips were then washed briefly in PBST (90\% phosphatebuffered saline (PBS), 10\% fetal bovine serum (FBS), 0.05\% Triton X-100), permeabilized in permeabilization buffer (90\% PBS, 10\% FBS, 0.5\% Triton X-100) for 15 minutes and blocked in PBST at RT for $1 \mathrm{~h}$. Cover slips were incubated with primary antibody solution at RT for $1 \mathrm{hr}$. Primary antibodies were diluted in PBST to a concentration of $2 \mu \mathrm{g} / \mathrm{ml}$. The primary antibodies used were mouse antiNANOG (MABD24, EMD Millipore), Goat anti-OCT3/4 (sc-8628, Santa Cruz), Rabbit anti-SOX2 (AB5603, Chemicon), and Goat anti-PAX6 (PRB-278P-100, Covance Inc.). The coverslips were then washed three times with PBST at RT for 10 minutes. Next, the secondary antibody diluted in PBST to a concentration of $2 \mu \mathrm{g} / \mathrm{ml}$ was added and the samples were incubated in the dark at RT for $1 \mathrm{~h}$. Secondary antibodies used are donkey anti-rabbit 488 (A21206, Invitrogen), donkey anti-goat 568 (A-11057,
Invitrogen), goat anti-mouse 633 (A-21050, Invitrogen) and rabbit anti-goat 488 (A-11055, Invitrogen). The coverslips were again washed three times with PBST at RT for 10 minutes. Finally, the coverslips were mounted using $3 \mu \mathrm{l}$ Vectashield mounting medium with DAPI (H-1200, Vectorlabs), after which fluorescence was detected by confocal microscopy (Leica TCS SPE). The same acquisition settings were used for all samples throughout each experiment.

\section{RNA extraction and sequencing}

Samples for RNA sequencing were collected at days 0, 7 , and 10 of neural differentiation of cell lines UMCU14 and UMCU15 from the patient, UMCU30 from the mother, and UMCU23 (with technical replicate) and UMCU32 from the father. RNA extraction was performed with Trizol (Life Technologies) according to the manufacturer's protocol. The isolated RNA was poly(A) selected with the MicroPoly(A) Purist Kit (Life Technologies) and a subsequent CAP-selection was performed with the mRNA ONLY Eukaryotic mRNA isolation kit (Epicentre/Illumina). Next, the RNA was heat sheared followed by hybridization and ligation to the SOLID adapters according to the SOLID sequencing protocol. The RNA was subsequently reverse transcribed using the SOLID RT primer. After size-selection of the complementary DNA, it was amplified using a SOLID PCR primer and a unique barcoding primer for each library. Samples were sequenced on a SOLID Wildfire. RNA sequencing of patient and parental blood samples was performed previously [19].

\section{Analysis of RNA sequencing data}

Reads were mapped to the human reference genome (GRCh37/hg19) using Burrows-Wheeler Aligner (BWA) [30]. The $\mathrm{R}$ package GenomicAlignments v1.6.3 was used to count reads overlapping exons [31]. DESeq v1.22.1 was used to normalize read counts for library size and differential expression was calculated using the DESeq nBinomtest function [32]. Hierarchical clustering based on the expression of the 500 genes with highest variance between all iPSC and neural progenitor cell (NPC) samples was performed using heatmap. 2 from the gplots R package v2.17.0 (https://cran.r-project.org/web/ packages/gplots/). Expression profiles of day 7 and day 10 NPCs clustered together and were therefore merged for downstream analysis (Additional file 1: Figure S1). Genes with more than ten normalized counts were considered expressed genes. Molecular effects were defined as gene expression differences of at least twofold between patient and parents. Circos plots for data visualization were generated using Circos software [33]. 


\section{$\mathrm{Hi}-\mathrm{C}$ data generation and analysis}

iPSC-derived NPCs of the patient (lines UMCU14 and UMCU15) and the father (UMCU23 and UMCU32) were crosslinked with $2 \%$ formaldehyde for 10 minutes. The crosslinking reaction was quenched by $0.125 \mathrm{M}$ glycine. Following the crosslinking procedure, samples were centrifuged at $400 \mathrm{~g}$ at $4{ }^{\circ} \mathrm{C}$ for 8 minutes. Pelleted cells were washed with PBS and centrifuged again at $400 \mathrm{~g}$ at $4{ }^{\circ} \mathrm{C}$ for 5 minutes. Cells were lysed in $1 \mathrm{~mL}$ freshly prepared lysis buffer $(50 \mathrm{mM}$ Tris $\mathrm{pH} 7.5,150 \mathrm{mM} \mathrm{NaCl}$, 5 mM EDTA, $0.5 \%$ NP-40, 1\% Triton X-100, and 1x complete EDTA-free Protease Inhibitor Cocktail (Roche)) on ice for 10 minutes. Nuclei were washed twice in cold PBS after completion of the cell lysis.

Isolated and cross-linked NPC nuclei were digested with the DpnII restriction enzyme (New England Biolabs). Subsequently, the proximity ligation of interacting fragments was performed using T4 DNA ligase (Roche) to produce the $3 \mathrm{C}$ template, according to a previously described protocol by Simonis et al. [34]. After reverse crosslinking and precipitation, $10 \mu \mathrm{g}$ of the template was sheared in microtubes (AFA Fiber Pre-Slit Snap-Cap $6 \times 16 \mathrm{~mm}, 520045)$ using the Covaris S2 sonicator (1 cycle of $25 \mathrm{~s}$; duty cycle $5 \%$, intensity 3, 200 cycles per burst, frequency sweeping). Fragments that ranged in size from 500 to $1500 \mathrm{bp}$ were selected using a $2 \%$ agarose gel. Size-selected fragments $(1.1 \mu \mathrm{g})$ were used as the input for the TruSeq DNA Low Sample (LS) protocol (Illumina). Constructed libraries were size-selected using a LabChip XT DNA 750 Assay Kit (Caliper), resulting in libraries between 800 and 950 bp. These Hi-C libraries were sequenced in a paired-end manner on the Illumina HiSeq 2500, resulting in $2 \times 100$-bp reads. Sequenced read pairs were mapped independently using Burrows-Wheeler Aligner (BWA-0.7.5a; settings were bwa mem -c $100-\mathrm{M}$ ) [30] to the human reference genome (hg19). Reads were further processed as previously described [35].

\section{C-seq}

4C-seq libraries were generated from crosslinked iPSCderived NPCs of the patient (lines UMCU14 and UMCU15) and the father (UMCU23 and UMCU32) as previously described [36]. DpnII was used as primary restriction enzyme and NlaIII as secondary restriction enzyme. We PCR amplified $1.6 \mu \mathrm{g}$ of each $4 \mathrm{C}$ template for each of the viewpoints using the primers listed in Additional file 2: Table S1. The amplified 4C libraries were pooled, spiked with 30\% Phi X 174 DNA, and sequenced on the Illumina NextSeq500 platform in paired-end mode. Data were processed as previously described [37]. The $4 \mathrm{C}$-seq reads were normalized based on the total number of captured reads per sample. We analyzed 1.3 to 4.3 million mapped reads per viewpoint.

Locations of TADs in H1-hESC cells were determined by Dixon et al. [38] and obtained from http:// promoter.bx.psu.edu/hi-c/download.html. Enhancer activity determined by expanded 18-state ChromHMM analysis of H1-derived NPCs (E007) and primary foreskin fibroblasts (E056) was obtained from the Roadmap Epigenomics Mapping Consortium (http:// egg2.wustl.edu/roadmap/data/byFileType/chromhmm Segmentations/ChmmModels/core_K27ac/jointModel/ final). The dataset for the primary foreskin fibroblasts (E056) was selected because these cells have the highest TWIST1 RNA expression of all cell types analyzed by the Roadmap Consortium (data not shown).

\section{Molecular cloning}

CNTN3 was amplified from a CNTN3-containing plasmid (RG221979 Origene). An In Fusion cloning kit (Clontech) was used to clone the amplicon into an empty plasmid with a pCAG promoter. High expression and proper cellular localization of CNTN3 were confirmed by transfection of the pCAG CNTN3 plasmid into HEK293 cells followed by western blotting and immunofluorescence with an antibody that recognizes CNTN3 (AF5539; R\&D Systems; data not shown).

\section{In utero electroporations of CNTN3 overexpression plasmids}

Animal use and care was in accordance with institutional and national guidelines (Dierexperimentencommissie). At E14.5, pregnant $\mathrm{C} 57 \mathrm{Bl} / 6$ mice were anesthetized using isoflurane (induction $3-4 \%$, surgery $1.5-2 \%$ ) and sedated with $0.05 \mathrm{mg} / \mathrm{kg}$ buprenorfin hydrochloride in saline. The abdominal cavity was opened and the uterine horns containing the embryos were carefully exposed. The lateral ventricles of the embryos were injected with linearized pCAG-CNTN3 or control DNA (linearized Nes714tk/lacZ) vectors dissolved in $0.05 \%$ Fast Green using glass micro-pipettes (Harvard Apparatus). Nes714tk/lacZ was a gift from Urban Lendahl (Addgene plasmid \#47614) [39]. pCAG-GFP was coinjected with the vectors to identify successfully electroporated cells. Developing cortices were targeted by electroporation with an ECM 830 Electro-SquarePorator (Harvard Apparatus) set to five unipolar pulses of $50 \mathrm{~ms}$ at $30 \mathrm{~V}$ (950-ms interval) using a platinum tweezer electrode holding the head (negative poles) and a third gold-plated Genepaddle electrode (positive pole) on top of the head (Fisher Scientific). Embryos were placed back into the abdomen and abdominal muscles and skin were sutured separately. 


\section{Immunofluorescent staining and analysis of brain sections}

In utero electroporated embryos were collected at E16.5 and heads were fixed in $4 \%$ paraformaldehyde and submerged in $30 \%$ sucrose followed by freezing in 2methylbutane. Sections of $20 \mu \mathrm{m}$ were cut on a cryostat, mounted on Superfrost Plus slides (Fisher Scientific), air-dried, and stored at $-20{ }^{\circ} \mathrm{C}$ until used for immunofluorescence. The sections were then blocked with $3 \%$ bovine serum albumin in PBS and $0.1 \%$ Triton, followed by an overnight incubation in rabbit anti-GFP (A11122, ThermoFisher Scientific) diluted in blocking solution. After washing with PBS the sections were incubated in goat anti-rabbit 488 diluted in blocking solution. Finally, the sections were counterstained with Hoechst and embedded in Fluorsafe before mounting on the coverslips. Cortices were imaged using conventional confocal microscopy using a Zeiss confocal microscope. Adobe Illustrator was used to place consistent rectangles divided in eight equal square bins on top of the acquired images, so that bin 1 starts at the ventricle border of the tissue and bin 8 ends at the pial surface. The number of GFPpositive cells were counted in each bin and divided by the total amount of cells in the rectangle.

\section{Results}

\section{Complex genomic rearrangements caused by} chromothripsis in an MCA/MR patient

Previously we performed RNA-seq on blood samples of an MCA/MR patient with germline chromothripsis and both parents. The phenotype of this patient includes craniosynostosis (premature fusion of one or more cranial sutures), facial dysmorphisms, duplication of the right thumb, pre- and postnatal growth retardation, and intellectual disability. Mate-pair and breakpoint junction sequencing showed that the genome of the patient contains 17 breakpoints on chromosomes $1,3,7$, and 12 (Fig. 1a) [7]. Molecular phenotypes detected in blood could not entirely explain the patient's phenotype. Not all genes in proximity to the breakpoints were expressed in the patient's blood samples, so we hypothesized that essential molecular effects that may have contributed to the patient phenotype were undetectable in the patient blood samples.

To obtain cell types relevant for the disease phenotype we generated three iPSC lines from the germline chromothripsis patient and differentiated two of these to the neural lineage (Fig. 1b). iPSCs were generated by reprogramming CD34-positive peripheral blood mononuclear cells (PBMCs) by transduction of a multicistronic lentiviral construct containing the canonical reprogramming factors $[28,40]$. We also successfully generated two control iPSC lines from the father and one line from the mother. Karyotyping confirmed the presence of all four derivative chromosomes in the patient's iPSC lines (Additional file 1: Figure S2). One of the patient's cell lines contained a duplication of derivative chromosome 1 (Additional file 1: Figure S2b). The paternal lines contained normal chromosome numbers, but the cell line of the mother has a translocation between chromosome 20 and part of chromosome 1 (Additional file 1: Figure S2c). Because these karyotype abnormalities are distant from the breakpoints and because three of the five lines had the expected karyotypes, we concluded that these lines were suitable to study the effects of the rearrangements within $1 \mathrm{Mb}$ of the breakpoints. All iPSCs expressed the pluripotencyassociated factors OCT4, SOX2, and NANOG, as
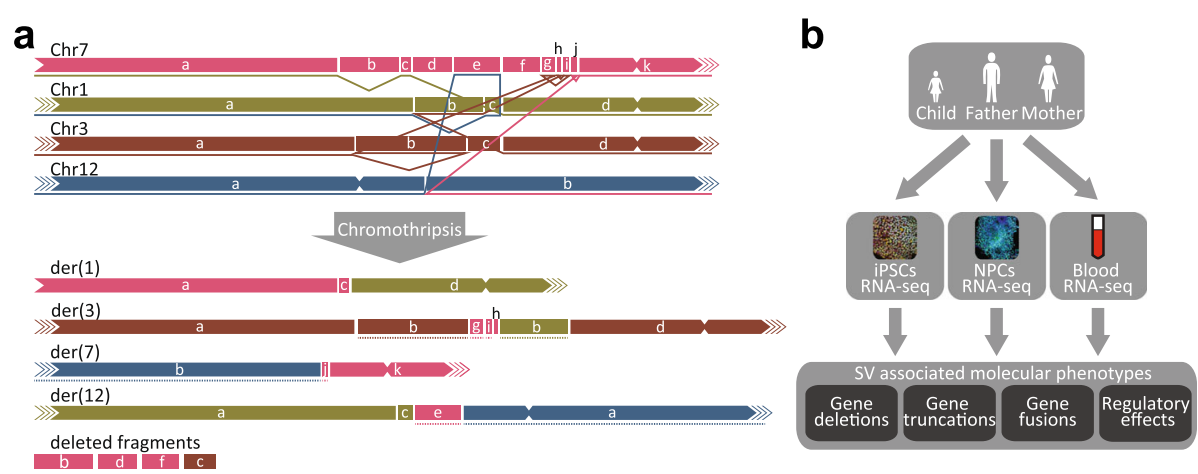

Fig. 1 Overview of complex chromosomal rearrangements in the patient with MCA/MR and study design. a The breakpoint locations and genomic rearrangements on the four affected chromosomes in the germline chromothripsis patient determined by mate-pair and breakpoint fusion sequencing. Inversions are depicted with dashed lines beneath the derivative chromosomes. The four deleted fragments are shown below the derivative chromosomes. This illustration is adapted from van Heesch et al. [19]. b Overview of the experimental setup of this study. Molecular effects of the chromosomal rearrangements on deleted, truncated, and fused genes and genes within 1 Mb of the rearrangements were determined by trio-based RNA-seq of iPSCs and iPSC-derived neuronal cells from the patient and both parents. These data were compared with previously generated expression data of blood samples of the patient and parents to identify molecular phenotypes that contribute to the patient's phenotype but are not detectable in blood [19] 
determined by immunofluorescence and western blotting (Additional file 1: Figure S3a, b). RNA-seq confirmed high expression of pluripotency factors in the iPSCs (Additional file 1: Figure S3c). Neural progenitor cells (NPCs) derived from the patient's and parents' iPSCs formed neural rosettes and expressed early neural markers such as PAX6, OTX1, OTX2, SOX1, and SOX11 (Additional file 1: Figure S4).

\section{Molecular profiling of iPSC-derived neural progenitors}

To identify molecular consequences of the chromothripsis rearrangements we performed RNA-seq on the iPSC lines and the iPSC-derived NPCs of the patient and the parents. We systematically analyzed the expression patterns of deleted genes, genes with disrupted coding sequences, and differentially expressed genes in close proximity to the breakpoints. Sixty-seven protein-coding genes are located across or within $1 \mathrm{Mb}$ from the rearrangements (Fig. 2; Additional file 3: Table S2). Sixty (89\%) of these are expressed in at least one of the samples. Ten genes are located on three deleted fragments (Fig. 3; Additional file 1: Figure S5). Four of these hemizygously deleted genes (SNX13 (OMIM:606589), TMEM106B (OMIM:613413), AHR (OMIM:600253) and ARL4A (OMIM:604786)) show a consistent reduced expression in all patient's samples compared to the parents' samples (Fig. 3; Additional file 1: Figure S5). Although in theory the loss of these genes on the affected paternal alleles may have contributed to the patient's phenotype through haploinsufficiency, none of these genes have previously been associated with any of the patient's symptoms in the literature and were therefore considered unlikely to have played a

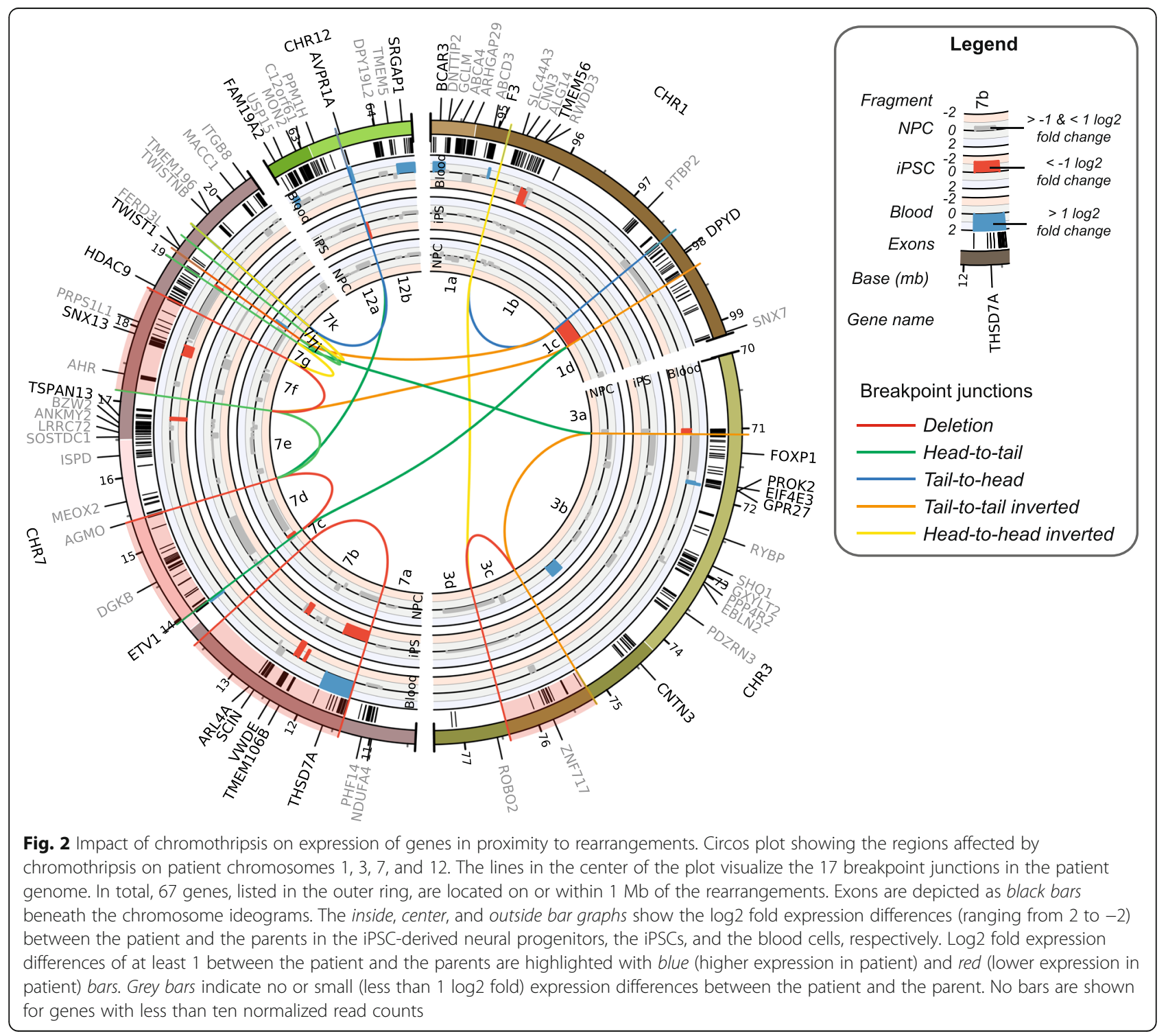




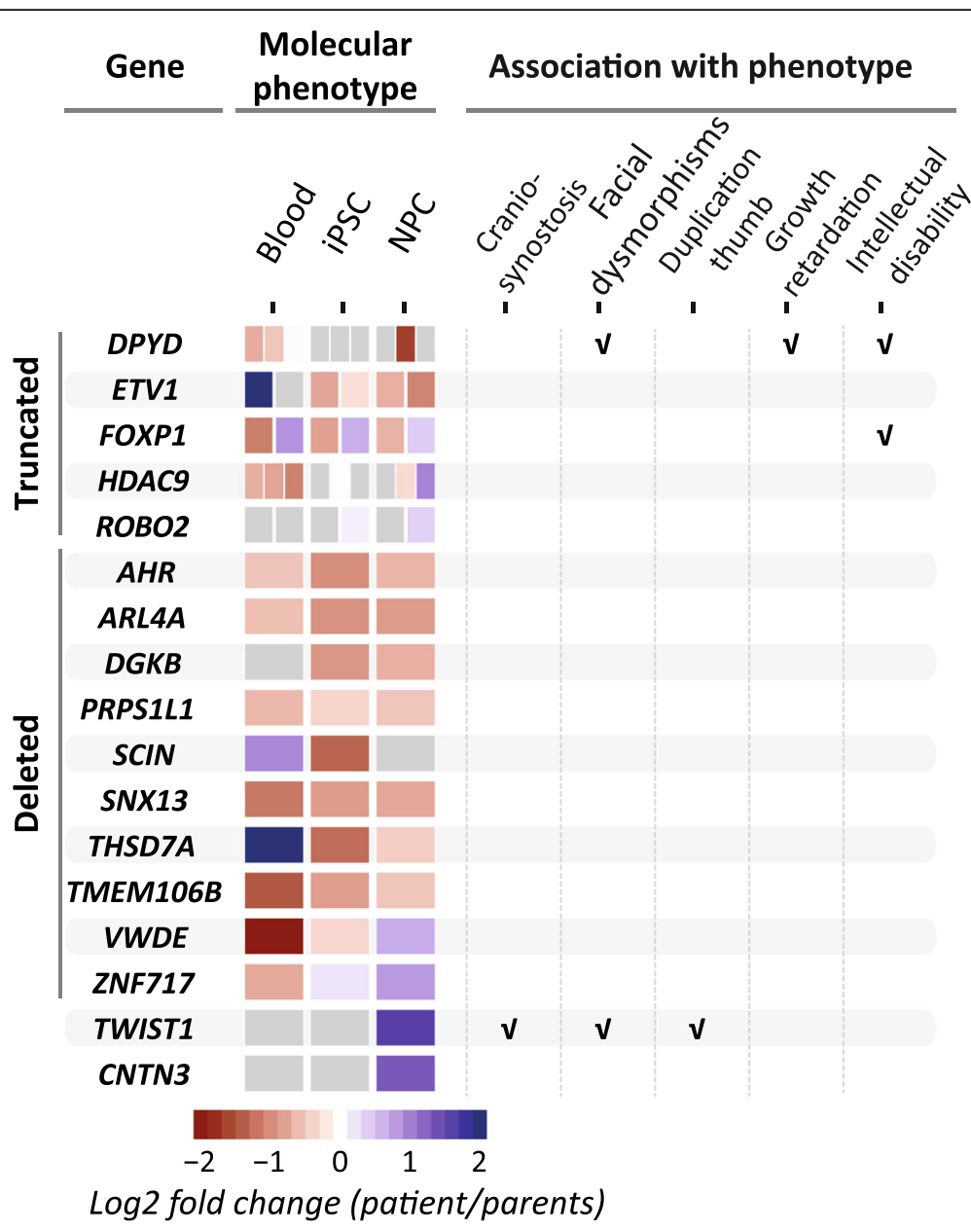

Fig. 3 Overview of molecular phenotypes and their association with the patient's phenotype. Selection of the genes located near the breakpoints with affected coding sequences and/or altered expression. The heatmap indicates the log2 fold expression differences between the patient and the parents in the three different cell types. Expression changes of the truncated genes are split into separate boxes for each gene fragment. Grey boxes are shown for genes with less than ten normalized read counts. More details are provided in Additional file 3: Table S2 and Additional file 4: Table S3

major role in disturbing the development of the patient (Fig. 3; Additional file 4: Table S3).

\section{Expression-dependent molecular effects on broken genes}

The coding sequences of six genes have been interrupted by the rearrangements (Fig. 4). Of these six disrupted genes, only AGMO (TMEM195) is not expressed in any of the assessed cell types. The $5^{\prime}$ part of FOXP1 is fused to an inverted region on chromosome 7 containing parts of the HDAC9 gene. The two disrupted genes are fused in opposite orientation and therefore do not directly form a fusion protein. However, we previously showed that there is read-through transcription from the $5^{\prime}$ part of FOXP1 to the other strand of chromosome 7, leading to expression of a short fusion protein [19]. The $5^{\prime}$ fused part of FOXP1 is expressed at higher levels in the cells derived from the patient in comparison with the cells of the parents (Fig. 4a). In contrast, the 3' fragment of FOXP1 shows a reduction in expression of $55 \%$ on average in the patient's cells (Fig. 4a). The $3^{\prime}$ part of ETV1 is fused to the $5^{\prime}$ part of DPYD and this DPYD-ETV1 fusion gene shows strong expression in blood cells [19] but not in the iPSCs and iPSC-derived neural progenitors (Fig. $4 \mathrm{~b}, \mathrm{c}$ ). The expression of DPYD-ETV1 is driven by the activity of the DPYD promoter, which is strong in blood but low in iPSCs and neural progenitors. The unaffected maternal ETV1 allele is only expressed in the iPSCs and iPSC-derived neural progenitors, but at the RNA level expression of this allele cannot completely compensate for the loss of the paternal allele in these cell types (Fig. 4c). Both DPYD and HDAC9 are disrupted by two breakpoints, but these breakpoints only have a minor impact on the expression of these genes in the assessed cell types [19] (Fig. 4b, d). 

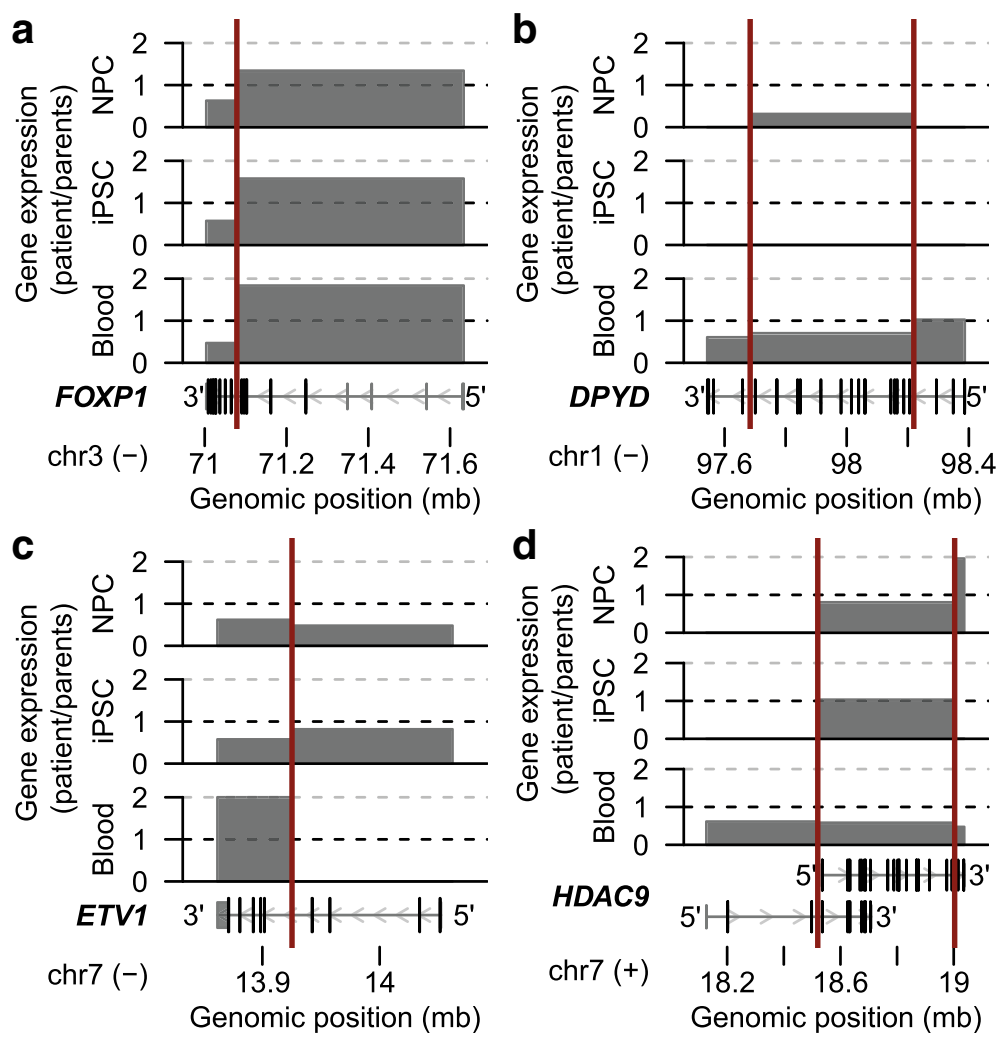

Fig. 4 Altered expression patterns of genes with disrupted coding sequences. Relative expression differences of disrupted genes a FOXP1 (NM_032682), b DPYD (NM_000110), c ETV1 (NM_001163152), and d HDAC9 (NM_001204144 and NM_178423) between the patient and parents in the iPSC-derived NPCs, iPSCs, and blood cells. Gene structures of the RefSeq transcripts described above are shown below the graphs. Vertical red lines indicate the breakpoint locations. Minus and plus signs indicate the DNA strand. Expression is not shown for fragments with less than ten normalized read counts in the patient or the parents

Of these six disrupted genes, FOXP1 (OMIM:605515) and DPYD (OMIM:612779) are associated with (neuro-)developmental disorders and may thus be relevant for the patient phenotype (Fig. 3; Additional file 4: Table S3). FOXP1 is an essential transcription factor involved in the development of many tissues, including the brain [41]. Heterozygous disruptions of FOXP1 have been found in several patients with neurodevelopmental disorders, including intellectual disability, autism spectrum disorder, and motor development delay [41]. $D P Y D$ encodes DPD (dihydropyrimidine dehydrogenase), an enzyme involved in the catabolism of pyrimidine bases [42]. Most carriers of heterozygous DPYD mutations are healthy, but some patients with hemizygous deletions affecting DPYD have neurodevelopmental disorders, including autism spectrum disorders [43-45], schizophrenia [46], epilepsy [47], and intellectual disability [42, 48, 49]. The disrupted coding sequences, altered expression, and association with congenital disease make it likely that the disruptions of FOXP1 and possibly DPYD contributed to the developmental delay and intellectual disability of the patient. However, none of the broken or deleted genes have been associated with craniosynostosis, one of the major phenotypic appearances of the patient (Fig. 3; Additional file 4: Table S3).

\section{Overexpression of TWIST1 and CNTN3 in the patient's iPSC-derived NPCs}

Two genes that are located on inverted regions, but are not deleted or truncated, TWIST1 and CNTN3, show a more than twofold difference in RNA expression in the NPCs derived from the patient in comparison to the parental cells (Fig. 5). Both genes are hardly expressed in blood cells and the coding sequences of these genes are not disrupted by the rearrangements, indicating that positional effects rather than gene dosage cause their misexpression. CNTN3 (also known as contactin-3, $P A N G$, or BIG-1) is a member of the contactin family of neural cell adhesion molecules, but little is known about the specific functions of CNTN3 [50-52]. CNTN3 is mainly expressed postnatally in specific subsets of neurons and promotes neurite outgrowth in isolated rat neurons $[52,53]$. Copy number changes of close family members CNTN4, CNTN5, and CNTN6 have been associated with autism spectrum disorders $[54,55]$. We hypothesized that misexpression of CNTN3 in neural progenitor cells may 


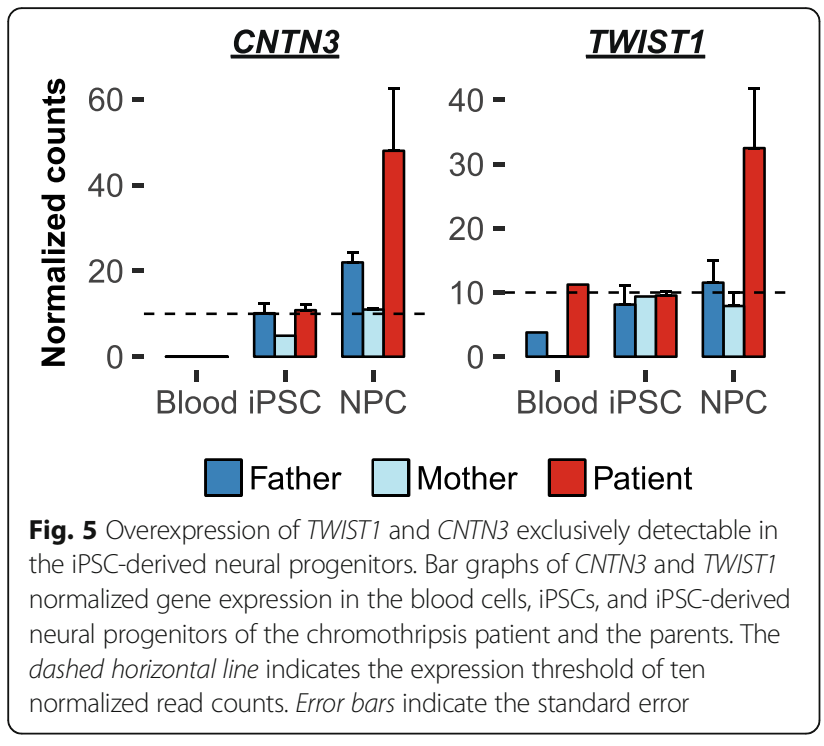

have affected the proper differentiation and migration of the patient's cortical neurons. To test this hypothesis we performed in utero electroporations of CNTN3 overexpression plasmids in neural progenitors of the developing mouse cortices. In this experiment we did not detect any change in the migration of neurons in the cortical layers (Additional file 1: Figure S6). We therefore consider it unlikely that misexpression of CNTN3 has interfered with this developmental process in the patient.

Deregulation of TWIST1 associated with patient's phenotype The other overexpressed gene located near the breakpoints in the patient NPCs is TWIST1, a basic helix-loop-helix (bHLH) factor essential for mesoderm and neural crest development, including the morphology and migration of head mesenchyme cells [56]. TWIST1 mutations and deletions (OMIM: 601622) are the main cause of Saethre-Chotzen syndrome (OMIM: 101400), characterized by craniosynostosis and limb abnormalities, including polydactyly, brachydactyly, and syndactyly [57, 58]. Several craniosynostosis patients with translocation breakpoints near TWIST1 have been described [59-61]. The phenotypes of these patients largely resemble the phenotype of the patient described in this study. Overexpression of TWIST1 has been shown to inhibit osteoblast differentiation in vitro and overexpression of Twist 1 in mouse embryonic limbs lead to reduced limb size [62-64]. Ectopic TWIST1 expression may disturb the balance between TWIST1, its dimerization partners such as HAND2 and TCF12, and its competitors for binding partners [65-67]. In general, however, the phenotypes of patients with TWIST1 mutations and deletions are linked to TWIST1 haploinsufficiency [58]. In addition, trisomy of the 7p15.3pter locus including the TWIST1 gene has been associated with delayed closure of the fontanels, the opposite phenotype of the patient described in this study and patients with TWIST1 haploinsuffiency $[68,69]$.

The overexpression of TWIST1 in the NPCs derived from the patient indicates a disturbed transcription regulation. We hypothesized that this deregulation may have led to decreased TWIST1 expression in neural crest and mesodermal cell types, resulting in a phenotype parallel to that of patients who have haploinsufficiency of this gene. To test this hypothesis, we investigated the regulatory landscape surrounding the TWIST1 gene. First we performed $\mathrm{Hi}-\mathrm{C}$ to determine the genomic interactions on the derivative chromosomes in the patient. The topologically associated domain (TAD) structures of the unaffected chromosomes of the patient and father are similar to the previously published TAD structures by Dixon and colleagues [38] (Fig. 6; Additional file 1: Figure S7). Disruption of TAD boundaries can cause ectopic interactions between gene promoters and enhancers and this may lead to disease [16]. Thirteen TADs are directly affected by the breakpoints in the patient and five TAD boundaries are deleted (Fig. 6; Additional file 1: Figure S7). Many ectopic genomic interactions cross the breakpoint junctions on the derivative chromosomes of the patient. For example, many interactions between the genomic regions of chromosome 1, 3, and 7 that form derivative chromosome 3 in the patient are not present in the father (Fig. 6). We could not precisely discern between reads of the unaffected maternal and affected paternal alleles and therefore could not specifically determine the genomic architecture of the derivative chromosomes.

Secondly, we performed 4C-seq on the NPCs of the patient and the father using TWIST1 as bait to determine potential gains and losses of genomic interactions of TWIST1 in the patient. TWIST1 mostly interacts with a region encompassing three putative TADs in the NPCs of the father (Fig. 7a). These three TADs are disrupted by five breakpoints in the patient and parts of these TADs are inverted or translocated away from TWIST1. These disrupted TWIST1 TADs contain several mesodermal enhancers active in cells with high TWIST1 expression and known TWIST1 enhancers (Fig. 7a) [70-72]. The TWIST1 $4 \mathrm{C}$-seq shows that there are losses of interactions between these enhancers and TWIST1 in the patient (Fig. 7a, red highlights). These losses of contacts with several of its enhancers could lead to reduced TWIST1 expression in neural crest-derived cells involved in craniosynostosis and possibly contribute to the craniosynostosis phenotype [58].

In addition, the 4C-seq experiments show that TWIST1 gained aberrant interactions with several enhancers active in neural progenitor cells (Fig. 7b, green highlights; Additional file 1: Figure S8). It is likely that these ectopic enhancer interactions drive the overexpression of TWIST1 in the NPCs of the patient. Thus, 


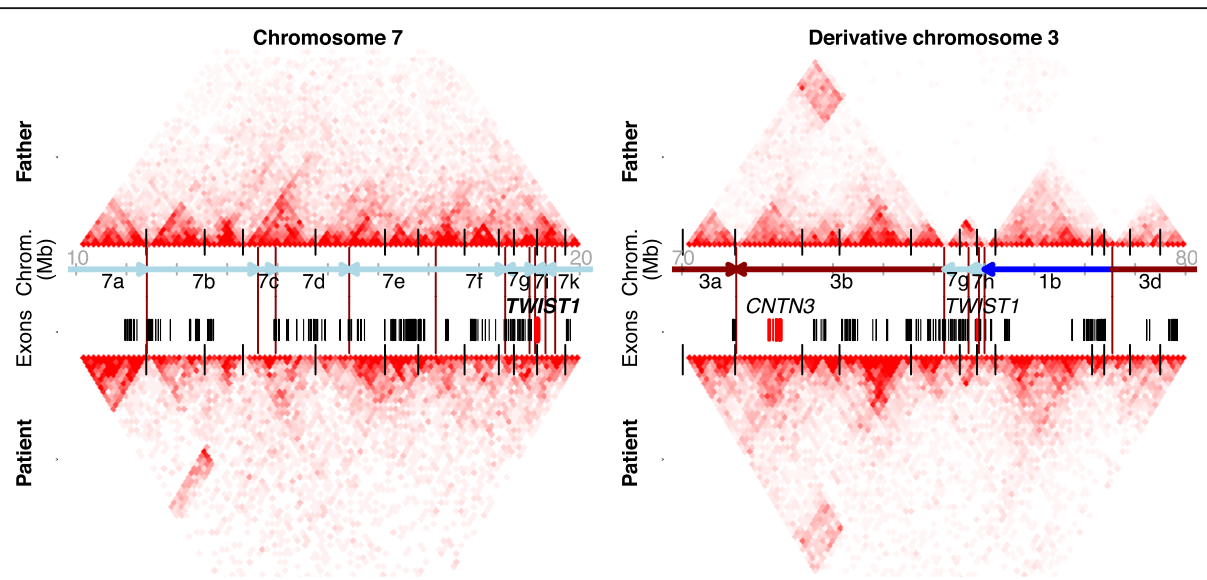

Fig. 6 Gains of genomic interactions on the derivative chromosomes of the patient. Hi-C chromatin interaction maps of the patient's (cell line UMCU15, bottom panels) and father's (cell line UMCU23, top panels) chromosome 7 (left panels) and derivative chromosome 3 (right panels). Interactions are shown at 100-kb resolution. The vertical black lines at the bases of the heatmaps depict the predicted TAD boundaries in hESCs as determined by Dixon et al. [38]. Vertical red lines between the interaction maps indicate the breakpoint locations in the patient

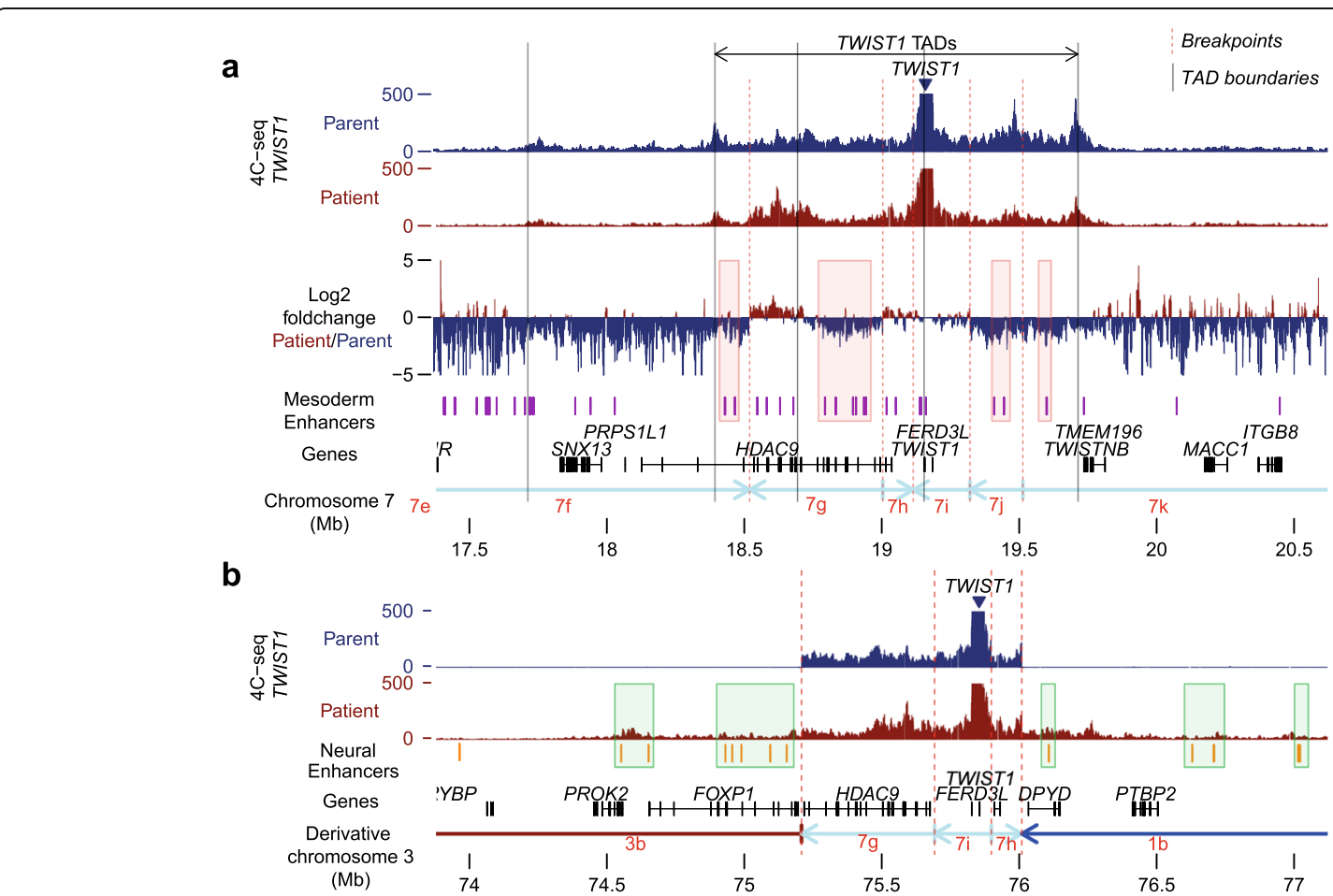

Fig. 7 Gains and losses of enhancer interactions with the TWIST1 locus in the patient. a 4C-seg data show that TWIST1 mainly contacts a region encompassing three TADs (termed TWIST1 TADs) in the NPCs of the father (cell line UMCU23). The $y$-axis indicates the number of normalized 4Cseq reads cutoff at 500 normalized reads. TAD boundaries in H1-ESCs were determined by Hi-C analysis by Dixon et al. [38]. ChromHMM analysis of Roadmap ChIP-seq data of primary fibroblasts with high TWIST1 expression indicates that these TWIST1 TADs contain multiple enhancers active in mesodermal cells (shown in purple). The TWIST1 4C-seq data of the patient's NPCS (UMCU15) shows that TWIST1 has reduced interactions with several of these enhancers (red highlights), which likely had an impact on TWIST1 expression in the patient. $\mathbf{b}$ The 4C-seq data, depicted on the derivative chromosome 3 in the patient, shows that TWIST1 gained several ectopic contacts with enhancers active in neural cells in the patient. Enhancer activity was obtained from ChromHMM analysis of Roadmap ChIP-seq data of NPCs derived from differentiation of hESCs. 4C-seq using two of these enhancers as baits confirms the ectopic interactions between the enhancers and TWIST1 (Additional file 1: Figure S8). These ectopic interactions may explain the overexpression of TWIST1 in the patient's NPCS 
chromosome conformation capture data suggest that TWIST1 has lost interactions with mesodermal enhancers and has gained new interactions with enhancers that are active in neurons, which may explain deregulation of TWIST1 expression in the patient. The resemblance with phenotypes of patients with TWIST1 mutations, deletions, and translocations strongly suggests a causative role of the TWIST1 deregulation in the development of the phenotype of our patient. This important molecular phenotype with a likely impact on the phenotype of the patient is only detectable in the patient iPSC-derived NPCs.

\section{Discussion}

We determined the molecular effects of complex chromosomal rearrangements by transcriptome analyses on blood cells, iPSCs, and iPSC-derived neural progenitors from an MCA/MR patient with chromothripsis. In addition, we performed chromosome conformation capture analyses on the iPSC-derived neural progenitors to study the genomic architecture of the derivative chromosomes. We confirmed several previously identified direct effects of the breakpoints on gene expression, such as reduced expression of several hemizygously deleted genes and misexpression of fused (DPYD-ETV1) and truncated genes (FOXP1 and ETV1) [19]. In addition, some genes that are located near the breakpoints but are not directly affected by the breakpoints (TWIST1 and CNTN3) were differentially regulated in the patient, indicating effects of the rearrangements on the regulatory DNA landscape. The altered expression of TWIST1, loss of genomic interactions with several of its enhancers, and the resemblance of the patient phenotype with TWIST1 +/- patients indicate that the TWIST1 deregulation is a major cause of the patient phenotype. The effect on TWIST1 expression was not detectable in the blood cells of the patient, highlighting the importance of using disease-relevant cell types for the interpretation of the consequences of genomic rearrangements.

Although genomic rearrangements caused by chromothripsis are non-recurrent, the effects of complex rearrangements on the phenotype of a patient may be inferred from patients with similar phenotypes caused by less complex genomic rearrangements. In this study, especially the detected deregulation of TWIST1 expression, which was only detected in the patient iPSC-derived NPCs, may explain a large part of the patient phenotype (the craniosynostosis and the doubling of the thumbs). The coding sequence of TWIST1 is not affected by the rearrangements, but translocations near TWIST1 have been found before in patients with similar phenotypes [59-61]. Effects on TWIST1 expression would have been difficult to predict by only studying the genomic variation of the patient, which demonstrates the importance of transcriptome analysis by RNA-seq to detect such effects in disease-relevant cell types. 4C-seq analyses showed that TWIST1 gained and lost interactions with several enhancers, which could have led to the deregulation of the normal gene expression in different cell types. This example of TWIST1 misexpression due to positional effects highlights the importance of not focusing solely on copy number changes or truncated and fused genes when studying the effects of chromosomal rearrangements [14]. This is further underscored by our finding that only half of the deleted genes in this patient show a consistent reduced expression, suggesting dosage compensation at the RNA level for the other half of the deleted genes. With our approach, we narrowed down a list of 67 candidate genes within $1 \mathrm{Mb}$ of the breakpoints to a list of three genes that likely contribute to the patient's phenotype.

Only a minority of the $T W I S T 1^{+/-}$patients show signs of developmental delay and intellectual disability like those observed for the patient described in this study. It is very well possible that a combination of molecular effects led to the complex phenotype of the patient. For example, the disrupted FOXP1 and DPYD genes are known MCA/MR genes that may have contributed to the intellectual disability and developmental delay in our patient. We cannot exclude that there are additional molecular effects in other cell types that also have contributed to the phenotype.

\section{Conclusions}

By analyzing the transcriptomes of blood cells, iPSCs, and iPSC-derived neuronal cells of a chromothripsis patient and both parents we identified the functional effects of the rearrangements that likely have contributed to the patient's phenotype. In particular we observed a cell typespecific effect of the rearrangements on the expression of TWIST1, even though the coding sequence of this gene was not disrupted by the rearrangements. This study shows the power of transcriptome and chromosome conformation capture analyses to detect effects of structural rearrangements on both coding sequences and regulatory elements. We identified clinically relevant molecular effects specific to the iPSC-derived neuronal cells. These findings underscore the importance of using diseaserelevant cell types to better understand the molecular effects of chromosomal rearrangements.

\section{Additional files}

Additional file 1: Document containing all supplemental figures and legends. (PDF 30908 kb)

Additional file 2: Table S1. Primer sequences used for each viewpoint in the 4C-seq experiments. Primer sequences are shown without the sequences of the sequencing primer and the P5 and P7 Illumina adaptors. (XLSX $10 \mathrm{~kb}$ ) 
Additional file 3: Table S2. Normalized RNA expression values for all 67 protein-coding genes located near the breakpoints. Expression levels of fragments of genes disrupted by the chromothripsis breakpoints are shown separately. Log2 fold expression changes between the patient and parents of more than 1 or less than -1 and $p$ values of less than 0.05 are highlighted in red. Differential expression was calculated using DESeq nbinomTest. (XLSX $31 \mathrm{~kb}$ )

Additional file 4: Table S3. Associations of genes located near the breakpoints with human and mouse disease phenotypes. Associations of the genes with human disease phenotypes were obtained from the MalaCards human disease database (http://www.malacards.org/; only phenotypes with a score of more than 1 are included). Mouse embryonic expression data were retrieved from the Gene Expression Database (GXD) from Mouse Genome Informatics (http://www.informatics.jax.org/ expression.shtml) and the eMouseAtlas (http://www.emouseatlas.org/). Phenotypes of homozygous mouse knockouts were obtained from Mouse Genome Informatics (http://www.informatics.jax.org/). Data were not available for all genes. (XLSX $23 \mathrm{~kb}$ )

\section{Abbreviations}

FBS: Fetal bovine serum; hESC: Human embryonic stem cell; IL: Interleukin; iPSC: Induced pluripotent stem cell; Mb: megabase; MCA/MR: Multiple congenital abnormalities and/or mental retardation; NPC: Neural progenitor cell; PBMC: Peripheral blood mononuclear cell; PBS: Phosphate-buffered saline; RT: Room temperature; TAD: Topologically associated domain; TPO: Thrombopoietin.

\section{Acknowledgements}

We are grateful to Anko de Graaff from the Hubrecht Imaging Center and Livio Kleij for their support with imaging. We thank Carlo Vermeulen and Geert Geeven from the Hubrecht Institute for their help with the 4C-seq experiments. We are also grateful to Elzo de Wit from the Netherlands Cancer Institute (NKI) for assistance with $\mathrm{Hi}-\mathrm{C}$ data analysis. We would also like to thank the Utrecht Sequencing Facility (USF) for sequencing.

\section{Funding}

This work was financially supported by a Vici grant (865.13.004) from the Netherlands Science Foundation (NWO) to EC.

\section{Availability of data and materials}

The RNA-seq, Hi-C, and 4C-seq datasets supporting the conclusions of this article have been deposited in the European Genome-phenome Archive (EGA; https://www.ebi.ac.uk/ega/home) under the accession number EGAS00001001896.

\section{Authors' contributions}

EWK, SvH, WPK, and EC designed the study. KB and EK generated and cultured the iPSC lines. EWK and MK performed iPSC culturing, in vitro differentiation, and immunofluorescence stainings. EWK performed confocal microscopy, RNA extractions, preparation of RNA-seq libraries, immunofluorescent staining and analysis of brain sections, and cloning of overexpression constructs. SM, JdL, MvR, MS, and Mvl analyzed sequencing data. SvH performed Hi-C and SM performed 4C-seq. RH performed karyotyping. NV and El provided patient information. YA and JP performed in utero electroporations. SM, EWK, and EC wrote the manuscript. All authors contributed to the final version of the manuscript. All authors read and approved the final manuscript.

\section{Competing interests}

MS is an employee of Cergentis. The remaining authors declare that they have no competing interests.

\section{Consent for publication}

\section{Not applicable.}

\section{Ethics approval and consent to participate}

Written informed consent to participate in this study was obtained from the parents of the pediatric patient. Genetic analyses were performed according to the guidelines of the Medical Ethics Committee of the University Medical Center Utrecht. The study was performed in accordance with the Declaration of Helsinki. Animal use and care were in accordance with institutional and national guidelines and approved by the Animal Ethic Committee (DEC) of the Utrecht University.

\section{Author details}

${ }^{1}$ Center for Molecular Medicine and Cancer Genomics Netherlands, Division Biomedical Genetics, University Medical Center Utrecht, Universiteitsweg 100, Utrecht 3584CG, The Netherlands. ${ }^{2}$ Cardiovascular and Metabolic Sciences, Max-Delbrück-Center for Molecular Medicine (MDC) in the Helmholtz Association, Robert-Rössle-Strasse 10, Berlin 13125, Germany. ${ }^{3}$ Department of Cell Biology, Center for Molecular Medicine and Regenerative Medicine Center, University Medical Center Utrecht, Uppsalalaan 6, Utrecht 3584CT, The Netherlands. ${ }^{4}$ Department of Molecular Epidemiology, Leiden University Medical Center, Einthovenweg 20, Leiden 2333ZC, The Netherlands. ${ }^{5}$ Cergentis B.V., Yalelaan 62, Utrecht 3584CM, The Netherlands. ${ }^{6}$ MRC Human Genetics Unit, Institute of Genetics and Molecular Medicine, University of Edinburgh, Crewe Road, Edinburgh EH4 2XU, UK. ${ }^{7}$ Department of Pediatric Pulmonology \& Laboratory of Translational Immunology, Wilhelmina Children's Hospital, University Medical Centre, Lundlaan 6, Utrecht 3584EA, The Netherlands. ${ }^{8}$ Department of Genetics, University Medical Center Utrecht, Lundlaan 6, Utrecht 3584EA, The Netherlands. ${ }^{9}$ Department of Translational Neuroscience, Brain Center Rudolf Magnus, University Medical Center Utrecht, Universiteitsweg 100, Utrecht 3584CG, The Netherlands.

Received: 12 July 2016 Accepted: 6 January 2017

Published online: 26 January 2017

\section{References}

1. Stankiewicz P, Lupski JR. Structural variation in the human genome and its role in disease. Annu Rev Med. 2010;61:437-55.

2. Cooper GM, Coe BP, Girirajan S, Rosenfeld JA, Vu TH, Baker C, Williams C, Stalker H, Hamid R, Hannig V, Abdel-Hamid H, Bader P, McCracken E, Niyazov D, Leppig K, Thiese H, Hummel M, Alexander N, Gorski J, Kussmann J, Shashi V, Johnson K, Rehder C, Ballif BC, Shaffer LG, Eichler EE. A copy number variation morbidity map of developmental delay. Nat Genet. 2011;43:838-46.

3. Miller DT, Adam MP, Aradhya S, Biesecker LG, Brothman AR, Carter NP, Church DM, Crolla JA, Eichler EE, Epstein CJ, Faucett WA, Feuk L, Friedman JM, Hamosh A, Jackson L, Kaminsky EB, Kok K, Krantz ID, Kuhn RM, Lee C, Ostell JM, Rosenberg C, Scherer SW, Spinner NB, Stavropoulos DJ, Tepperberg JH, Thorland EC, Vermeesch JR, Waggoner DJ, Watson MS, et al. Consensus statement: Chromosomal microarray is a first-tier clinical diagnostic test for individuals with developmental disabilities or congenital anomalies. Am J Hum Genet. 2010;86:749-64.

4. Kaminsky EB, Kaul V, Paschall J, Church DM, Bunke B, Kunig D, Moreno-DeLuca D, Moreno-De-Luca A, Mulle JG, Warren ST, Richard G, Compton JG, Fuller AE, Gliem TJ, Huang S, Collinson MN, Beal SJ, Ackley T, Pickering DL, Golden DM, Aston E, Whitby H, Shetty S, Rossi MR, Rudd MK, South ST, Brothman AR, Sanger WG, lyer RK, Crolla JA, et al. An evidence-based approach to establish the functional and clinical significance of copy number variants in intellectual and developmental disabilities. Genet Med. 2011;13:777-84

5. Hochstenbach R, Buizer-Voskamp JE, Vorstman JAS, Ophoff RA. Genome arrays for the detection of copy number variations in idiopathic mental retardation, idiopathic generalized epilepsy and neuropsychiatric disorders: Lessons for diagnostic workflow and research. Cytogenet Genome Res. 2011;135:174-202

6. Stephens PJ, Greenman CD, Fu B, Yang F, Bignell GR, Mudie LI, Pleasance ED, Lau KW, Beare D, Stebbings LA, McLaren S, Lin M-L, McBride DJ, Varela I, Nik-Zainal S, Leroy C, Jia M, Menzies A, Butler AP, Teague JW, Quail MA, Burton J, Swerdlow H, Carter NP, Morsberger LA, lacobuzio-Donahue C, Follows GA, Green AR, Flanagan AM, Stratton MR, et al. Massive genomic rearrangement acquired in a single catastrophic event during cancer development. Cell. 2011;144:27-40.

7. Kloosterman WP, Tavakoli-Yaraki M, van Roosmalen MJ, van Binsbergen E, Renkens I, Duran K, Ballarati L, Vergult S, Giardino D, Hansson K, Ruivenkamp CAL, Jager M, van Haeringen A, Ippel EF, Haaf T, Passarge E, Hochstenbach R, Menten B, Larizza L, Guryev V, Poot M, Cuppen E. Constitutional chromothripsis rearrangements involve clustered double-stranded DNA breaks and nonhomologous repair mechanisms. Cell Rep. 2012;1:648-55.

8. Chiang C, Jacobsen JC, Ernst C, Hanscom C, Heilbut A, Blumenthal I, Mills RE, Kirby A, Lindgren AM, Rudiger SR, McLaughlan CJ, Bawden CS, Reid SJ, 
Faull RLM, Snell RG, Hall IM, Shen Y, Ohsumi TK, Borowsky ML, Daly MJ, Lee C, Morton CC, MacDonald ME, Gusella JF, Talkowski ME. Complex reorganization and predominant non-homologous repair following chromosomal breakage in karyotypically balanced germline rearrangements and transgenic integration. Nat Genet. 2012;44:390-7.

9. Kloosterman WP, Cuppen E. Chromothripsis in congenital disorders and cancer: similarities and differences. Curr Opin Cell Biol. 2013;25:341-8.

10. Kloosterman WP, Guryev V, van Roosmalen M, Duran KJ, de Bruijn E, Bakker SCM, Letteboer T, van Nesselrooij B, Hochstenbach R, Poot M, Cuppen E. Chromothripsis as a mechanism driving complex de novo structural rearrangements in the germline. Hum Mol Genet. 2011;20:1916-24.

11. Redin C, Brand H, Collins RL, Kammin T, Mitchell E, Hodge JC, Hanscom C, Pillalamarri V, Seabra CM, Abbott M-A, Abdul-Rahman OA, Aberg E, Adley R, Alcaraz-Estrada SL, Alkuraya FS, An Y, Anderson M-A, Antolik C, AnyaneYeboa K, Atkin JF, Bartell T, Bernstein JA, Beyer E, Blumenthal I, Bongers EMHF, Brilstra EH, Brown CW, Brüggenwirth HT, Callewaert B, Chiang C, et al. The genomic landscape of balanced cytogenetic abnormalities associated with human congenital anomalies. Nat Genet. 2016;49(1):36-45.

12. Weischenfeldt J, Symmons O, Spitz F, Korbel JO. Phenotypic impact of genomic structural variation: insights from and for human disease. Nat Rev Genet. 2013;14:125-38.

13. Kloosterman WP, Hochstenbach R. Deciphering the pathogenic consequences of chromosomal aberrations in human genetic disease. Mol Cytogenet. 2014;7:100

14. Spielmann M, Mundlos S. Structural variations, the regulatory landscape of the genome and their alteration in human disease. Bioessays. 2013;35:533-43.

15. Poot M, Haaf T. Mechanisms of origin, phenotypic effects and diagnostic implications of complex chromosome rearrangements. Mol Syndromol. 2015;6:110-34

16. Lupiáñez DG, Spielmann M, Mundlos S. Breaking TADs: how alterations of chromatin domains result in disease. Trends Genet. 2016;32:225-37.

17. Schlattl A, Anders S, Waszak SM, Huber W, Korbel JO. Relating CNVs to transcriptome data at fine resolution: Assessment of the effect of variant size, type, and overlap with functional regions. Genome Res. 2011;21:2004-13.

18. Luo R, Sanders SJ, Tian Y, Voineagu I, Huang N, Chu SH, Klei L, Cai C, Ou J, Lowe JK, Hurles ME, Devlin B, State MW, Geschwind DH. Genome-wide transcriptome profiling reveals the functional impact of rare de novo and recurrent CNVs in autism spectrum disorders. Am J Hum Genet. 2012;91:38-55.

19. van Heesch S, Simonis M, van Roosmalen MJ, Pillalamarri V, Brand H, Kuijk EW, de Luca KL, Lansu N, Braat AK, Menelaou A, Hao W, Korving J, Snijder S, van der Veken LT, Hochstenbach R, Knegt AC, Duran K, Renkens I, Alekozai $\mathrm{N}$, Jager $\mathrm{M}$, Vergult $\mathrm{S}$, Menten $\mathrm{B}$, de Bruijn $\mathrm{E}$, Boymans $\mathrm{S}$, Ippel $\mathrm{E}$, van Binsbergen E, Talkowski ME, Lichtenbelt K, Cuppen E, Kloosterman WP. Genomic and functional overlap between somatic and germline chromosomal rearrangements. Cell Rep. 2014;9:2001-10.

20. Blumenthal I, Ragavendran A, Erdin S, Klei L, Sugathan A, Guide JR, Manavalan P, Zhou JQ, Wheeler VC, Levin JZ, Ernst C, Roeder K, Devlin B, Gusella JF, Talkowski ME. Transcriptional consequences of 16p11.2 deletion and duplication in mouse cortex and multiplex autism families. Am J Hum Genet. 2014;94:870-83.

21. Cai C, Langfelder P, Fuller TF, Oldham MC, Luo R, van den Berg LH, Ophoff RA, Horvath S. Is human blood a good surrogate for brain tissue in transcriptional studies? BMC Genomics. 2010;11:589.

22. Tylee DS, Kawaguchi DM, Glatt SJ. On the outside, looking in: a review and evaluation of the comparability of blood and brain "-omes.". Am J Med Genet Part B Neuropsychiatr Genet. 2013;162:595-603.

23. Grskovic M, Javaherian A, Strulovici B, Daley GQ. Induced pluripotent stem cells-opportunities for disease modelling and drug discovery. Nat Rev Drug Discov. 2011;10:915-29.

24. Bellin M, Marchetto MC, Gage FH, Mummery CL. Induced pluripotent stem cells: the new patient? Nat Rev Mol Cell Biol. 2012;13:713-26.

25. Avior Y, Sagi I, Benvenisty N. Pluripotent stem cells in disease modelling and drug discovery. Nat Rev Mol Cell Biol. 2016;17:170-82.

26. Cundiff PE, Anderson SA. Impact of induced pluripotent stem cells on the study of central nervous system disease. Curr Opin Genet Dev. 2011;21:354-61.

27. Dolmetsch R, Geschwind DH. The human brain in a dish: the promise of iPSC-derived neurons. Cell. 2011;145:831-4.

28. Warlich E, Kuehle J, Cantz T, Brugman MH, Maetzig T, Galla M, Filipczyk AA, Halle S, Klump H, Schöler HR, Baum C, Schroeder T, Schambach A. Lentiviral vector design and imaging approaches to visualize the early stages of cellular reprogramming. Mol Ther. 2011;19:782-9.
29. Shi Y, Kirwan P, Livesey FJ. Directed differentiation of human pluripotent stem cells to cerebral cortex neurons and neural networks. Nat Protoc 2012;7:1836-46.

30. Li H, Durbin R. Fast and accurate short read alignment with BurrowsWheeler transform. Bioinformatics. 2009;25:1754-60.

31. Lawrence M, Huber W, Pagès H, Aboyoun P, Carlson M, Gentleman R, Morgan MT, Carey VJ. Software for computing and annotating genomic ranges. PLoS Comput Biol. 2013;9:e1003118.

32. Anders S, Huber W. Differential expression analysis for sequence count data. Genome Biol. 2010;11:R106.

33. Krzywinski M, Schein J, Birol I, Connors J, Gascoyne R, Horsman D, Jones SJ, Marra MA. Circos: an information aesthetic for comparative genomics. Genome Res. 2009:19:1639-45.

34. Simonis M, Klous $P$, Splinter $E$, Moshkin $Y$, Willemsen $R$, de Wit $E$, van Steensel B, de Laat W. Nuclear organization of active and inactive chromatin domains uncovered by chromosome conformation capture-on-chip (4C). Nat Genet. 2006;38:1348-54.

35. Krijger PHL, Di Stefano B, de Wit E, Limone F, van Oevelen C, de Laat W, Graf T. Cell-of-origin-specific 3D genome structure acquired during somatic cell reprogramming. Cell Stem Cell. 2015;18:597-610.

36. Splinter $\mathrm{E}$, de Wit $\mathrm{E}$, van de Werken HJG, Klous $\mathrm{P}$, de Laat W. Determining long-range chromatin interactions for selected genomic sites using $4 \mathrm{C}$-seq technology: from fixation to computation. Methods. 2012;58:221-30.

37. Van De Werken HJG, De Vree PJP, Splinter E, Holwerda SJB, Klous P, De Wit E, De Laat W. 4C technology: protocols and data analysis. Methods Enzymol. 2012;513:89-112.

38. Dixon JR, Selvaraj S, Yue F, Kim A, Li Y, Shen Y, Hu M, Liu JS, Ren B. Topological domains in mammalian genomes identified by analysis of chromatin interactions. Nature. 2012:485:376-80.

39. Lothian C, Lendahl U. An evolutionarily conserved region in the second Intron of the human nestin gene directs gene exmession to CNS progenitor cells and to early neural crest cells. Eur J Neurosci. 1997;9:452-62.

40. Takahashi K, Tanabe K, Ohnuki M, Narita M, Ichisaka T, Tomoda K, Yamanaka S. Induction of pluripotent stem cells from adult human fibroblasts by defined factors. Cell. 2007;131:861-72.

41. Bacon C, Rappold GA. The distinct and overlapping phenotypic spectra of FOXP1 and FOXP2 in cognitive disorders. Hum Genet. 2012;131:1687-98.

42. Van Kuilenburg ABP, Vreken P, Abeling NGGM, Bakker HD, Meinsma R, Van Lenthe H, De Abreu RA, Smeitink JAM, Kayserili H, Apak MY, Christensen E, Holopainen I, Pulkki K, Riva D, Botteon G, Holme E, Tulinius M, Kleijer WJ, Beemer FA, Duran M, Niezen-Koning KE, Smit GPA, Jakobs C, Smit LME, Moog U, Spaapen LM, Van Gennip AH. Genotype and phenotype in patients with dihydropyrimidine dehydrogenase deficiency. Hum Genet. 1999:104:1-9.

43. Carter MT, Nikkel SM, Fernandez BA, Marshall CR, Noor A, Lionel AC, Prasad A, Pinto D, Joseph-George AM, Noakes C, Fairbrother-Davies C, Roberts W, Vincent J, Weksberg R, Scherer SW. Hemizygous deletions on chromosome 1 p21.3 involving the DPYD gene in individuals with autism spectrum disorder. Clin Genet. 2011:80:435-43.

44. Prasad A, Merico D, Thiruvahindrapuram B, Wei J, Lionel AC, Sato D, Rickaby J, Lu C, Szatmari P, Roberts W, Fernandez BA, Marshall CR, Hatchwell E, Eis PS, Scherer SW. A discovery resource of rare copy number variations in individuals with autism spectrum disorder. G3 (Bethesda). 2012;2:1665-85.

45. Pinto D, Delaby E, Merico D, Barbosa M, Merikangas A, Klei L, Thiruvahindrapuram B, Xu X, Ziman R, Wang Z, Vorstman JA, Thompson A, Regan R, Pilorge M, Pellecchia G, Pagnamenta AT, Oliveira B, Marshall CR, Magalhaes TR, Lowe JK, Howe JL, Griswold AJ, Gilbert J, Duketis E, Dombroski BA, De Jonge MV, Cuccaro M, Crawford EL, Correia CT, Conroy J, et al. Convergence of genes and cellular pathways dysregulated in autism spectrum disorders. Am J Hum Genet. 2014;94:677-94.

46. Xu B, lonita-Laza I, Roos JL, Boone B, Woodrick S, Sun Y, Levy S, Gogos JA, Karayiorgou M. De novo gene mutations highlight patterns of genetic and neural complexity in schizophrenia. Nat Genet. 2012;44:1365-9.

47. Lal D, Ruppert A-K, Trucks H, Schulz H, de Kovel CG, Kasteleijn-Nolst Trenité D, Sonsma ACM, Koeleman BP, Lindhout D, Weber YG, Lerche H, Kapser C, Schankin CJ, Kunz WS, Surges R, Elger CE, Gaus V, Schmitz B, Helbig I, Muhle H, Stephani U, Klein KM, Rosenow F, Neubauer BA, Reinthaler EM, Zimprich F, Feucht M, Møller RS, Hjalgrim H, De Jonghe P, et al. Burden analysis of rare microdeletions suggests a strong impact of neurodevelopmental genes in genetic generalised epilepsies. PLoS Genet. 2015;11:e1005226 
48. Willemsen MH, Valles A, Kirkels LAMH, Mastebroek M, Olde Loohuis N, Kos A, Wissink-Lindhout WM, de Brouwer APM, Nillesen WM, Pfundt R, HolderEspinasse M, Vallee L, Andrieux J, Coppens-Hofman MC, Rensen H, Hamel BCJ, van Bokhoven H, Aschrafi A, Kleefstra T. Chromosome 1p21.3 microdeletions comprising DPYD and MIR137 are associated with intellectual disability. J Med Genet. 2011;48:810-8.

49. D'Angelo CS, Moller Dos Santos MF, Alonso LG, Koiffmann CP. Two new cases of 1 p21.3 deletions and an unbalanced translocation t(8;12) among individuals with syndromic obesity. Mol Syndromol. 2015;6:63-70.

50. Shimoda Y, Watanabe K. Contactins: emerging key roles in the development and function of the nervous system. Cell Adh Migr. 2009;3:64-70.

51. Zuko A, Bouyain S, van der Zwaag B, Burbach JPH. Contactins: structural aspects in relation to developmental functions in brain disease. Adv Protein Chem Struct Biol. 2011;84:143-80.

52. Mohebiany AN, Harroch S, Bouyain S. New insights into the roles of the contactin cell adhesion molecules in neural development. Adv Neurobiol. 2014:8:165-94.

53. Yoshihara Y, Kawasaki M, Tani A, Tamada A, Nagata S, Kagamiyama H, Mori K. BIG-1: a new TAG-1/F3-related member of the immunoglobulin superfamily with neurite outgrowth-promoting activity. Neuron. 1994;13:415-26.

54. Zuko A, Kleijer KTE, Oguro-Ando A, Kas MJH, van Daalen E, van der Zwaag $\mathrm{B}, \mathrm{Burbach} \mathrm{JPH}$. Contactins in the neurobiology of autism. Eur J Pharmacol. 2013;719:63-74.

55. Morrow EM, Yoo S-Y, Flavell SW, Kim T-K, Lin Y, Hill RS, Mukaddes NM, Balkhy S, Gascon G, Hashmi A, Al-Saad S, Ware J, Joseph RM, Greenblatt R, Gleason D, Ertelt JA, Apse KA, Bodell A, Partlow JN, Barry B, Yao H, Markianos K, Ferland RJ, Greenberg ME, Walsh CA. Identifying autism loci and genes by tracing recent shared ancestry. Science. 2008;321:218-23.

56. Qin $Q, X u Y, H e T$, Qin C, Xu J. Normal and disease-related biological functions of Twist1 and underlying molecular mechanisms. Cell Res. 2012;22:90-106.

57. Cunningham ML, Seto ML, Ratisoontorn C, Heike CL, Hing AV. Syndromic craniosynostosis: from history to hydrogen bonds. Orthod Craniofac Res. 2007:10:67-81.

58. Twigg SRF, Wilkie AOM. A genetic-pathophysiological framework for craniosynostosis. Am J Hum Genet. 2015:97:359-77.

59. Rose CSP, Patel P, Reardon W, Malcolm S, Winter RM. The TWIST gene, although not disrupted in Saethre-Chotzen patients with apparently balanced translocations of 7p21, is mutated in familial and sporadic cases. Hum Mol Genet. 1997:6:1369-73.

60. Krebs I, Weis I, Hudler M, Rommens JM, Roth H, Scherer SW, Tsui LC, Füchtbauer EM, Grzeschik KH, Tsuji K, Kunz J. Translocation breakpoint maps $5 \mathrm{~kb} 3^{\prime}$ from TWIST in a patient affected with Saethre-Chotzen syndrome. Hum Mol Genet. 1997;6:1079-86.

61. Cai J, Goodman BK, Patel AS, Mulliken JB, Van Maldergem L, Hoganson GE, Paznekas WA, Ben-Neriah Z, Sheffer R, Cunningham ML, Daentl DL, Jabs EW. Increased risk for developmental delay in Saethre-Chotzen syndrome is associated with TWIST deletions: an improved strategy for TWIST mutation screening. Hum Genet. 2003;114:68-76.

62. Lee MS, Lowe GN, Strong DD, Wergedal JE, Glackin CA. TWIST, a basic helixloop-helix transcription factor, can regulate the human osteogenic lineage. J Cell Biochem. 1999;75:566-77.

63. Funato N, Ohtani K, Ohyama K, Kuroda T, Nakamura M. Common regulation of growth arrest and differentiation of osteoblasts by helix-loop-helix factors. Mol Cell Biol. 2001;21:7416-28.

64. Firulli BA, Redick BA, Conway SJ, Firulli AB. Mutations within helix I of Twist1 result in distinct limb defects and variation of DNA binding affinities. J Biol Chem. 2007;282:27536-46.

65. Firulli B, Krawchuk D, Centonze VE, Vargesson N, Virshup DM, Conway SJ, Cserjesi P, Laufer E, Firulli AB. Altered Twist1 and Hand2 dimerization is associated with Saethre-Chotzen syndrome and limb abnormalities. Nat Genet. 2005;37:373-81.

66. Connerney J, Andreeva V, Leshem Y, Muentener C, Mercado MA, Spicer DB. Twist1 dimer selection regulates cranial suture patterning and fusion. Dev Dyn. 2006;235:1334-46.

67. Sharma VP, Fenwick AL, Brockop MS, McGowan SJ, Goos JAC, Hoogeboom AJM, Brady AF, Jeelani NO, Lynch SA, Mulliken JB, Murray DJ, Phipps JM, Sweeney E, Tomkins SE, Wilson LC, Bennett S, Cornall RJ, Broxholme J, Kanapin A, Johnson D, Wall SA, van der Spek PJ, Mathijssen IMJ, Maxson RE, Twigg SRF, Wilkie AOM. Mutations in TCF12, encoding a basic helix-loop- helix partner of TWIST1, are a frequent cause of coronal craniosynostosis. Nat Genet. 2013;45:304-7.

68. Stankiewicz P, Thiele H, Baldermann C, Krüger A, Giannakudis I, Dörr S, Werner N, Kunz J, Rappold GA, Hansmann I. Phenotypic findings due to trisomy 7p15. 3-pter including the TWIST locus. Am J Med Genet. 2001;103:56-62.

69. Aswini S, Padmalatha VO, Saranya G, Durgadatta T, Raseswari T, Kulashekaran KM, Meena J, Chandra N, Lalji S, Kandukuri LR. De novo 7p partial trisomy characterized by subtelomeric FISH and whole-genome array in a girl with mental retardation. Mol Cytogenet. 2011;4:21.

70. Birnbaum RY, Clowney EJ, Agamy O, Kim MJ, Zhao J, Yamanaka T, Pappalardo Z, Clarke SL, Wenger AM, Nguyen L, Gurrieri F, Everman DB, Schwartz CE, Birk OS, Bejerano G, Lomvardas S, Ahituv N. Coding exons function as tissue-specific enhancers of nearby genes. Genome Res. 2012;22:1059-68.

71. Siekmann TE, Gerber MM, Toland AE. Variants in an Hdac9 intronic enhancer plasmid impact Twist1 expression in vitro. Mamm Genome. 2015;27(3-4):99-110.

72. Ernst J, Kellis M. ChromHMM: automating chromatin-state discovery and characterization. Nat Methods. 2012;9:215-6.

\section{Submit your next manuscript to BioMed Central and we will help you at every step:}

- We accept pre-submission inquiries

- Our selector tool helps you to find the most relevant journal

- We provide round the clock customer support

- Convenient online submission

- Thorough peer review

- Inclusion in PubMed and all major indexing services

- Maximum visibility for your research

Submit your manuscript at www.biomedcentral.com/submit
Biomed Central 